\title{
Structural reorganization of the cartilage tissue in chronic osteomyelitis of the foot bones
}

\author{
T.A. Stupina, N.S. Migalkin, A.S. Sudnitsyn
}

Russian Ilizarov Scientific Center for Restorative Traumatology and Orthopaedics, Kurgan, Russian Federation

\begin{abstract}
Purpose To study structural reorganization of the cartilage tissue of the joints, depending on the location of osteomyelitis in the bones of the foot. Materials and methods Intraoperative material of 16 patients with chronic osteomyelitis in the foot bones was studied ( 10 males in the average age $45.3(33 \div 56$ ) years and six females in the average age of $40(23 \div 53)$ years). The material was resected fragments of the osteo-cartilaginous complex: calcaneus, talus and adjacent joint tissue (subtalar and talo-navicular, phalangeal and metatarsal bones and metatarsophalangeal joint). The material was fixed in $10 \%$ formalin. Paraffin sections (5-7 $\mu \mathrm{m}$ thick) were stained with hematoxylin and eosin. Histological studies were performed using a stereo microscope "AxioScope.A1" with a digital camera "AxioCam” and software "Zenblue" (CarlZeiss MicroImaging GmbH, Germany). Results The subchondral bone plate and basophilic line remained continuous and the vessels did not penetrate into the cartilaginous tissue in chronic osteomyelitis of the calcaneus and talus, when the osteomyelitis foci were remote from the articular surface. If an osteomyelitic lesion was present in the subchondral zone, abnormalities in the articular cartilage were detected both from the side of the subchondral bone and on the articular surface; and vascular invasion was observed. In the deep zone of the cartilage, there were hypertrophic chondrocytes with signs of chondroptosis, what indicated a violation of the chondrohematic barrier. Disorders of the basophilic line and penetration of the bone marrow pannus were revealed. From the side of the articular surface, a synovial pannus was observed invading the cartilage matrix. In chronic osteomyelitis of the phalanges and metatarsal bones, regardless of the phase of the inflammatory process, in all observations, disorders in the structure of the subchondral bone plate and articular cartilage were detected; there was invasion of blood vessels from the subchondral zone and articular surface that might be explained by the small size of those bones. Conclusion The intensity of articular cartilage destruction in chronic osteomyelitis of the calcaneus and talus depended on the location of the osteomyelitis focus and the phase of the inflammatory process. In chronic osteomyelitis of the phalanges and metatarsal bones, regardless of the phase of the inflammatory process, there were disorders in the structure of the articular cartilage and vascular invasion. The findings on structural changes in the articular cartilage in chronic osteomyelitis of adjacent bones are helpful for defining the tactics of surgical treatment.

Keywords: chronic osteomyelitis, foot, articular cartilage, histopathology
\end{abstract}

\section{INTRODUCTION}

Osteomyelitic lesions in the foot bones account for about a tenth of all of the body's osteomyelitis [1]. From an anatomical point of view, the foot is a multicomponent structure consisting of many bones and joints which may unite several bones simultaneously. Treatment of osteomyelitis in the foot bones is time-consuming, and frequently fails. Amputation of the segment may be offered to patients [2, 3]. According to most researchers, successful treatment of chronic osteomyelitis implies radicalism regarding the osteomyelitis process, correct choice of the surgical technique and method of surgical intervention [4]. In this regard, the main diagnostic task is to obtain the most complete and objective evaluation of the nature of purulent and inflammatory changes in the bone and surrounding tissues.

Tissue damage may be quite extensive in chronic osteomyelitis of the foot, involving the joints in the inflammatory process [5]. Histopathological features of bone tissue in acute and chronic osteomyelitis have been described well [6]. Most reports of pathological changes in the cartilage tissue of joints in osteomyelitis are separate descriptions of clinical cases that develop osteoarthritis and synovitis of large joints [7, 8].

Our aim was to study structural reorganization of the cartilage tissue of the joints, depending on the location of osteomyelitis in the bones of the foot.

\section{MATERIAL AND METHODS}

Intraoperative material of 16 patients with chronic osteomyelitis in the foot bones was studied (10 males in the average age $45.3(33 \div 56)$ years and six females in the average age of $40(23 \div 53)$ years). Three patients among them suffered diabetic foot. All patients gave informed consent to conduct the studies required by the protocol. The study was conducted in accordance with the ethical standards

Ld Stupina T.A., Migalkin N.S., Sudnitsyn A.S. Structural reorganization of the cartilage tissue in chronic osteomyelitis of the foot bones. Genij Ortopedii, 2019, vol. 25, no 4, pp. 523-527. DOI 10.18019/1028-4427-2019-25-4-523-527. (In Russian) 
of the 1975 Helsinki Declaration, revised in 2008. The material was resected fragments of the osteocartilaginous complex: calcaneus, talus and adjacent joint tissue (subtalar and talo navicular, phalangeal and metatarsal bones and metatarsophalangeal joint). The material was fixed in $10 \%$ formalin. Paraffin sections $(5-7 \mu \mathrm{m}$ thick) were prepared following decalcification and stained with hematoxylin and eosin. Histological studies were performed using a stereo microscope "AxioScope.A1" with a digital camera "AxioCam" and software "Zenblue" (CarlZeiss MicroImaging GmbH, Germany). Osteomyelitis phase was classified according to A. Tiemann et al. (2014).

\section{RESULTS}

Alight-optical study of the histological preparations revealed signs of chronic osteomyelitis in all patients (foci of osteonecrosis, sequestra, replacement of bone marrow structures with granulation tissue of different maturity, fibrosis, and presence of diffuse or focal inflammatory infiltration). Signs of reparative osteogenesis were also detected along with the signs of osteodestructive changes.

Among the patients diagnosed with chronic osteomyelitis of the calcaneus, five patients had a 3 point score according to Tiemann A. et al. (2014) [9] (subsided phase, remission,), four patients had 4 and 5 points (subacute course), and three patients had 6 or 7 points (period of exacerbation, active osteomyelitis).

The osteomyelitis focus was located at a remote distance from the articular lining in phases of remission and subacute course. The subchondral osseous plate was a mature bone of the osteon structure and it was continuous throughout (Fig. 1a). Signs of osteoporosis and bone trabeculae stretching were detected in the subchondral zone; fatty bone marrow prevailed in the interosseous spaces and granulation tissue fields were present; the perivascular inflammatory infiltrate consisted mainly of lymphoplasmacytic cell elements (Fig. 1b). The articular cartilage retained the zonal structure: the superficial, middle and deep zones could be defined (Fig. 1c). In the superficial zone, foci of defibration of different severity were observed from the superficial part to the upper part of the middle zone in all the cases. Chondrocytes with pyknotic nuclei were determined. In the middle zone, two-membered isogenic group number was increased; the column-like arrangement of cells was preserved in the deep zone, and cell-free regions were identified. The basophilic line was stratified in several sites but was integral. The zone of calcified cartilage in some areas was thinned or absent.

Bone necrosis of the subchondral zone with the involvement of the cartilage tissue of the joints was revealed in patients with chronic osteomyelitis in the exacerbation phase (diabetic foot). In the articular cartilage, changes occurred both from the side of the articular surface and from the subchondral zone (Fig. 2a). From the side of the subchondral zone, the structure of the subchondral bone plate was disordered; there were osteoclasts resorbing the main substance of the bone tissue (Fig. 2b). Areas in which there was no calcified cartilage zone were identified; the basophilic line was not determined; and the bone marrow pannus penetrated into the cartilage. On the articular surface, foci of defibration were found extending to the middle zone. Moreover, the chondrocytes of the superficial zone formed threeand four-member isogenic groups (Fig. 2c).


Fig. 1 Joint lining of the calcaneus in the area of the subtalar joint: $\boldsymbol{a}$ general view; $\boldsymbol{b}$ perivascular inflammatory infiltrate in the subchondral zone; $c$ preserved zonal structure of the cartilage, defibration of the superficial zone. Hematoxylin and eosin staining. Magnification: $\times 31.25(\boldsymbol{a}), \times 250(\boldsymbol{b}), \times 78.75(\boldsymbol{c})$ 

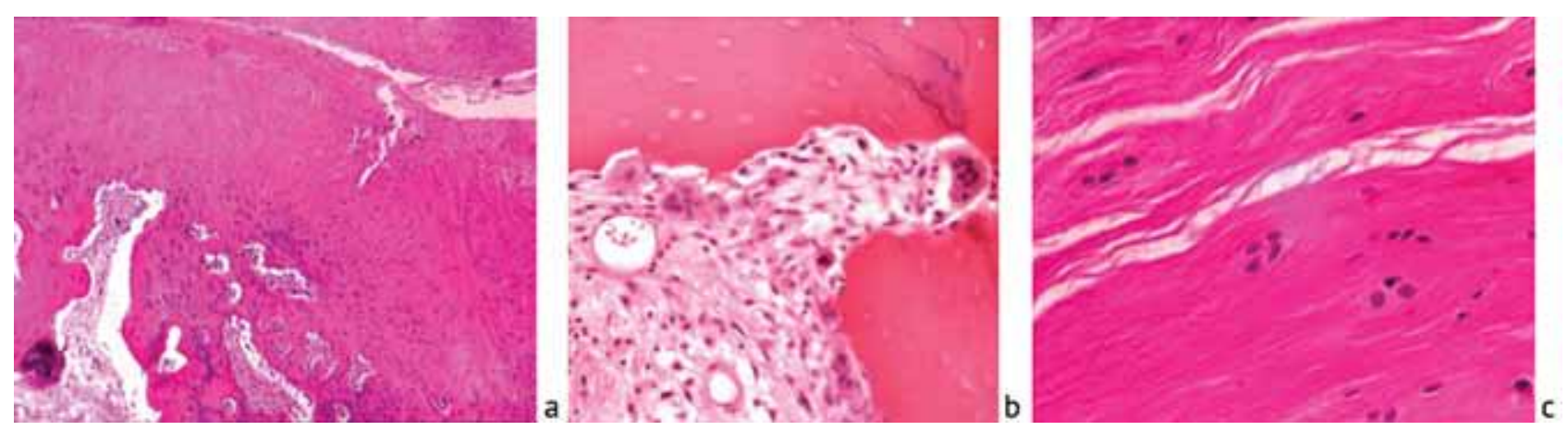

Fig. 2 Joint lining of the calcaneus in the area of the subtalar joint: $\boldsymbol{a}$ general view; $\boldsymbol{b}$ osteoclast resorbing the main substance of the subchondral bone; $\boldsymbol{c}$ defibration of the superficial zone, three- and four-member isogenic groups of cells. Hematoxylin and eosin staining. Magnification $\times 31.25(\boldsymbol{a}), \times 250(\boldsymbol{b}), \times 200(\boldsymbol{c})$

In chronic osteomyelitis of the phalanges and metatarsal bones, a score on a scale of A. Tiemann et al. (2014) [9] was 2-3 points in 3 patients (remission phase), and 5 points in 1 patient (subacute course).

In all those patients, the structure of the articular cartilage of the metatarsophalangeal joints was disordered (Fig. 3a). Histopathological changes were resorption of the subchondral bone plate, its thinning or complete absence, penetration of the medullary pannus into the cartilage, and disorders in cytoarchitectonics.

On the articular surface, vascular fibrous tissue was detected as a layer (pannus); blood vessels penetrated into the superficial and middle zones of the cartilage. The cartilage under the pannus was thinned; dystrophic and necrotic changes in chondrocytes were noted; regeneration sites were isogenic groups of cartilage cells. In the middle zone, the interterritorial matrix was weakly stained, defibrated; chondrocytes were of an abnormal shape with signs of destruction (Fig. 3b). The main part of the chondrocytes of the deep zone was in the state of chondroptosis (Fig. 3c) [10, 11]. Such cells were characterized by significant heterochromatization of the nucleus and abundant vacuoles were found in the cytoplasm.
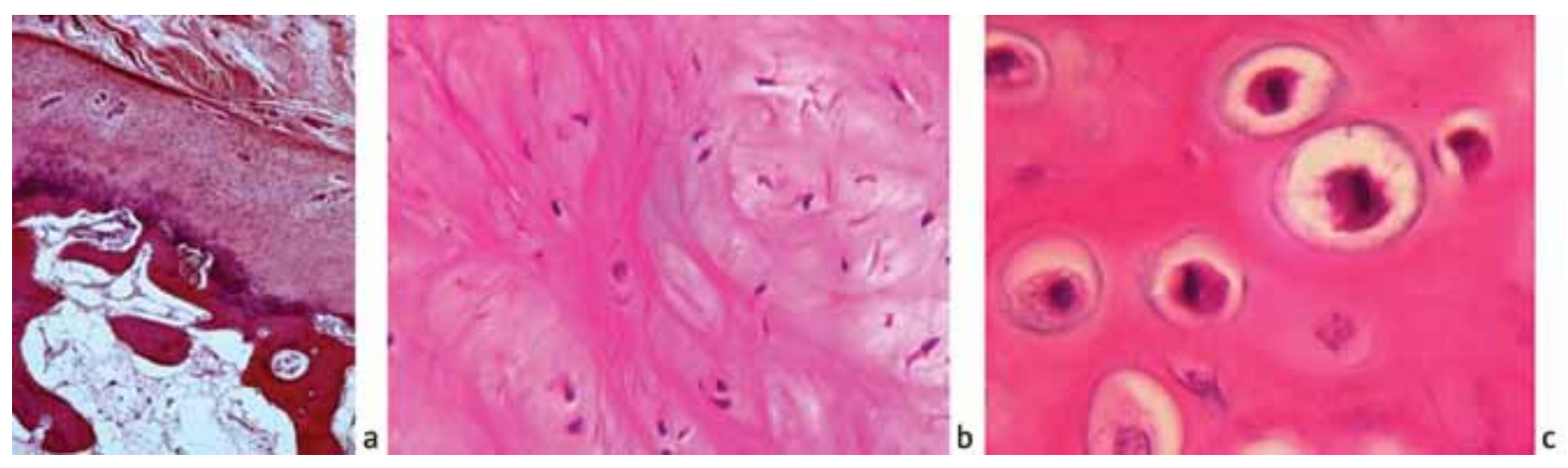

Fig. 3 Joint cartilage of the metatarsophalangeal joint: $\boldsymbol{a}$ general view; $\boldsymbol{b}$ middle zone; $\boldsymbol{c}$ chondrocytes of the deep zone. Hematoxylin and eosin staining. Magnification $\times 31.25(\boldsymbol{a}), \times 200(\boldsymbol{b}), \times 500(\boldsymbol{c})$

\section{DISCUSSION}

Chronic osteomyelitis of the foot bones, including in the diabetic foot, should be diagnosed early and accurately to ensure effective treatment and reduce the risk of extensive amputation $[12,13]$.

The "golden" standard is the histological method, which is one of the five special methods for the diagnosis of osteomyelitis [6].

The debatable question in amputation is whether to leave the cartilage [14] and use it as a "barrier" to prevent infection penetration from the underlying bone [15].
Articular cartilage is usually sterile. Bacteria can reach these sites through hematogenous way or spreading from exogenous or endogenous adjacent foci of infection [16].

Articular cartilage is a barrier to the spread of the osteomyelitis process, since intensely functioning hypertrophic chondrocytes form a chondrohematic barrier at the border to the subchondral bone plate; and the contact of the vessels with the cartilaginous tissue is blocked [17]. In pathological conditions, this 
"barrier" could be broken and blood vessels could penetrate into the cartilage.

The pathological changes in the articular cartilage due to chronic osteomyelitis, revealed in this study, depended on the location of the osteomyelitis focus. So, in chronic osteomyelitis of the calcaneus and talus, when the osteomyelitis focus is remote from the articular surface, the subchondral bone plate and basophilic line remained continuous; the vessels did not penetrate into the cartilaginous tissue. If an osteomyelitis lesion was located in the subchondral zone, abnormalities in the articular cartilage were revealed both from the side of the subchondral bone and from the articular surface. Moreover, there was an invasion of vessels into the cartilage tissue. In the deep cartilage zone, hypertrophic chondrocytes with signs of chondroptosis, what indicated a break in the chondrohematic barrier; the basophilic line was disordered and there was penetration of the bone marrow pannus. From the side of the articular surface, a synovial pannus was observed, invading the cartilage matrix.

The intensity of cartilage destruction depended on the inflammatory phase and was more pronounced in the diabetic foot.

In chronic osteomyelitis of the phalanges and metatarsal bones, regardless of the phase of the inflammatory process, there were disorders in the structure of the subchondral plate and articular cartilage in all the cases, and vascular invasion from the subchondral zone and articular surface that can be explained by small sizes of the bones.

The findings on structural changes in the articular cartilage in chronic osteomyelitis of the adjacent bones are helpful for defining the tactics of surgical treatment.

\section{REFERENCES}

1. Kliushin N.M., Aranovich A.M., Shliakhov V.I., Zlobin A.V. Novye tekhnologii lecheniia bolnykh khronicheskim osteomielitom itog sorokaletnego opyta primeneniia metoda chreskostnogo osteosinteza [New technologies for treatment of patients with chronic osteomyelitis - the outcome of forty-year experience of using transosseous osteosynthesis method]. Genij Ortopedii, 2011, no. 2, pp. 27-33. (in Russian)

2. Arias Arias C., Tamayo Betancur M.C., Pinzón M.A., Cardona Arango D., Capataz Taffur C.A., Correa Prada E. Differences in the clinical outcome of osteomyelitis by treating specialty: orthopedics or infectology. PLoS One, 2015, vol. 10, no. 12 , pp. e0144736. DOI: 10.1371/journal.pone.0144736.

3. Sudnitsyn A.S., Kliushin N.M., Shchurova E.N. Organosokhraniaiushchaia metodika lecheniia bolnykh s khronicheskim osteomielitom kostei golenostopnogo sustava i zadnego otdela stopy (sluchai iz praktiki) [The technique of organ-saving when treating patients with chronic osteomyelitis of the ankle and hindfoot bones (a case report)]. Genij Ortopedii, 2016, no. 2, pp. 9496. (in Russian)

4. Gostishchev V.K., Lipatov K.V., Pisarenko L.V., Rubin M.P., Stan E.A., Marakutsa E.V. Prognozirovanie izmenenii prochnosti dlinnykh trubchatykh kostei v khirurgii khronicheskogo osteomielita [Prediction of changes in long tubular bone strength in chronic osteomyelitis surgery]. Khirurgiia. Zhurnal im. N.I. Pirogova, 2010, no. 2, pp. 4-6. (in Russian)

5. Bairamkulov E.D., Vorotnikov A.A., Mozerov S.A., Krasovitova O.V. Kliniko-morfologicheskaia kharakteristika osteomielita pri sindrome diabeticheskoi stopy [Osteomyelitis clinicomorphological characteristic for diabetic foot syndrome]. Fundamentalnye Issledovaniia, 2015, no. 1-1, pp. 23-27. (in Russian)

6. Schmidt H.G., Tiemann A.H., Braunschweig R., Diefenbeck M., Bühler M., Abitzsch D., Haustedt N., Walter G., Schoop R., Heppert V., Hofmann G.O., Glombitza M., Grimme C., Gerlach U.J., Flesch I.; Arbeitsgemeinshaft septishe Chirurgie der DGOUC10. Definition of the Diagnosis Osteomyelitis-Osteomyelitis Diagnosis Score (ODS). Z. Orthop. Unfall., 2011, vol. 149, no. 4, pp. 449-460. DOI: 10.1055/s-0030-1270970.

7. Ellerbrook L., Laks S. Coccidioidomycosis osteomyelitis of the knee in a 23-year-old diabetic patient. Radiol. Case Rep., 2015, vol. 10, no. 1, pp. 1034. DOI: 10.2484/rcr.v10i1.1034.

8. Ahmad S.S., Kohl S., Evangelopoulos D.S., Krüger A. Silent chronic osteomyelitis lasting for 30 years before outburst of symptoms. BMJ Case Rep., 2013, April 22, bcr2013009428. DOI: 0.1136/bcr-2013-009428.

9. Tiemann A., Hofmann G.O., Krukemeyer M.G., Krenn V., Langwald S. Histopathological Osteomyelitis Evaluation Score (HOES) - an innovative approach to histopathological diagnostics and scoring of osteomyelitis. GMS Interdiscip. Plast. Reconstr. Surg. DGPW, 2014, vol. 3, Doc08. DOI: 10.3205/iprs000049.

10. Roach H.I., Aigner T., Kouri J.B. Chondroptosis: a variant of apoptotic cell death in chondrocytes? Apoptosis, 2004, vol. 9, no. 3, pp. 265-277.

11. Dedukh N.V., Bengus L.M., Tuliakov V.A., Batura I.A. Morfologiia sustavnogo khriashcha krys s kortikosteroidnoi distrofiei posle lecheniia kombinatsiei gliukozamina gidrokhlorida s paratsetamolom [Articular cartilage morphology of rats with corticosteroid dystrophy after treatment by combining glucosamine hydrochloride with paracetamol]. Visnik Problem Biologii i Meditsini, 2011, vol. 1, no. 2, pp. 291. (in Russian)

12. Nather A., Wong K.L. Distal amputations for the diabetic foot. Diabet. Foot Ankle, 2013, vol. 4. DOI: 10.3402/dfa.v4i0.21288.

13. Giurato L., Meloni M., Izzo V., Uccioli L. Osteomyelitis in diabetic foot: A comprehensive overview. World J. Diabetes, 2017, vol. 8, no. 4, pp. 135-142. DOI: 10.4239/wjd.v8.i4.135. 
14. Li A., Meunier M., Rennekampff H.O., Tenenhaus M. Surgical amputation of the digit: an investigation into the technical variations among hand surgeons. Eplasty, 2013, vol. 13, pp. e12.

15. Wilhelmi B.J. Digital Amputations Technique. Oct 30, 2017. Available at: emedicine.medscape.com>article/1238395-technique.

16. Calhoun J.H., Mader J. Musculoskeletal Infections. 1 edition, CRC Press, 2003, 648 p.

17. Zaidman A.M., Korel A.V. Strukturno-funktsionalnye osobennosti plastinki rosta tela pozvonka v kriticheskie periody rosta [Structural-and-functional features of vertebral body growth plate in critical periods of growth]. Khirurgiia Pozvonochnika, 2004, no. 1, pp. 113-120. (in Russian)

Received: 29.05.2018

\section{Information about the authors:}

1. Tatiana A. Stupina, Ph.D. of Biology,

Russian Ilizarov Scientific Center for Restorative Traumatology and Orthopaedics, Kurgan, Russian Federation, Email: StupinaSTA@mail.ru

2. Nikolai S. Migalkin,

Russian Ilizarov Scientific Center for Restorative Traumatology and Orthopaedics, Kurgan, Russian Federation 3. Anatolii S. Sudnitsyn, M.D., Ph.D.,

Russian Ilizarov Scientific Center for Restorative Traumatology and Orthopaedics, Kurgan, Russian Federation, Email: anatol_anatol@mail.ru 